${ }^{3}$ Monson RR, Yen S, MacMahon B. Chronic mastitis and carcinoma of the breast. Lancet 1976 ;ii :224-6.

${ }^{4}$ Kodlin D, Winger EE, Morgenstern NL, Chen U. Chronic mastopathy and breast cancer. Cancer $1977 ; 39: 2603-7$.

5 Page DL, Vander Zwaag R, Rogers NW, et al. Relation between component parts of fibrocystic disease complex and breast cancer. Fournal of the National Cancer Institute 1978;61:1055-64.

${ }^{6}$ Hutchinson WB, Thomas DB, Hablin WB, et al. Risk of breast cancer in women with benign breast disease. Fournal of the National Cancer Institute 1980;65:13-20.

7 Coombs LJ, Lilienfeld AM. A prospective study of the relationship between benign breast diseases and breast carcinoma. Prev Med 1979;8: 40-52.

${ }^{8}$ Haagenson CD, Bodian C, Haagenson DE. Breast carcinoma risk and detection. Philadelphia: WB Saunders Co, 1981:70-4.

${ }^{9}$ Duffy $S W$, Roberts MM, Elton RA. Risk factors for breast cancer: relevance to screening. $\mathcal{F}$ Epidemiol Community Health $1983 ; 37: 127-31$

10 Shapiro S, Strax P, Venet L, Fink R. The search for risk factors in breast cancer. Am $\mathcal{F}$ Public Health 1968;58:820-35.

11 Lubin JH, Burns PE, Blot WJ, et al. Risk factors for breast cancer in women in Northern Alberta, Canada, as related to age at diagnosis. fournal of the National Cancer Institute 1982;68:211-7.

12 Vessey MP, Doll R, Jones K, McPherson K, Yeates D. An epidemiological study of oral contraceptives and breast cancer. Br Med f 1979;i:1755-8.

${ }^{13}$ Paffenbarger RS, Kampert JB, Chang HG. Characteristics that predict risk of breast cancer before and after the menopause. Am $\mathcal{F}$ Epidemiol $1980 ; 112: 258-68$.
14 Wynder EL, MacCormack FA, Stellman SD. The epidemiology of breast cancer in 785 US Caucasian women. Cancer 1978;41:2341-54.

15 Brinton LA, Williams RR, Hoover RN, et al. Breast cancer risk factors among screening programme participants. Fournal of the National Cancer Institute 1979;62:37-44.

${ }^{16}$ Chamberlain J. Trial of early detection of breast cancer. Br $\mathcal{F}$ Cancer $1981 ; 44: 618-27$.

17 Sims ACP. Importance of a high tracing rate in long-term medical follow-up studies. Lancet 1973;ii :433-5.

18 Wellings SR, Jensen HM, Marcum RG. An atlas of subgross pathology of the human breast with special reference to possible precancerous lesions. Fournal of the National Cancer Institute 1975;55:231-73.

19 Wolfe J. Risk for breast cancer development determined by mammographic parenchymal patterns. Cancer 1976;37:2486-92.

20 Office of Population Censuses and Surveys. Report of the Advisory Committee on Cancer Registration, England and Wales. London: OPCS, 1980:18-22.

${ }^{21}$ Vessey MP, McPherson K, Johnson B. Mortality among women participating in the Oxford/Family Planning Association contraceptive study. Lancet $1977 ; \mathrm{ii}: 731-3$.

${ }^{22}$ Langlands AO, Kerr GR, Shaw S. The management of locally advanced breast cancer by $x$ ray therapy. Clin Oncol 1976;2:365-71.

${ }^{23}$ Cole P, Elwood JM, Kaplan SD. Incidence rates and risk factors of benign breast neoplasms. Am $\mathcal{F}$ Epidemiol 1978;108:112-20.

${ }^{24}$ Love SM, Gelman RS, Silen W. Fibrocystic "disease" of the breastnon-disease? N Engl f Med 1982;307:1010-4.

(Accepted 27 October 1983)

\title{
Infection after abdominal surgery: five year prospective study
}

\author{
Z H KRUKOWSKI, M P M STEWART, H M ALSAYER, N A MATHESON
}

\begin{abstract}
A total of 1504 consecutive abdominal operations were studied prospectively over a five year period. The incidence of wound $(2.8 \%)$ and intraperitoneal $(0.8 \%)$ infections was low compared with contemporary reports. It is difficult to justify modifying existing practice on the basis of small controlled clinical trials when information from accurate audit discloses results superior to those of experimental studies.
\end{abstract}

\section{Introduction}

The large amount of recent work that has gone into attempts to reduce septic complications after abdominal surgery has concentrated on choice of dose regimen for the appropriate agents and with few exceptions has not taken other technical factors into account. Antibiotics and antiseptics have had variable but always positive effects in reducing wound infection. In some instances, however, particularly in colonic surgery and perforated appendicitis, though the reduction has been real, a troublesome incidence of both wound and residual intraabdominal abscess persists. During the past .10 years we have

\footnotetext{
University Department of Surgery and Aberdeen Royal Infirmary, Aberdeen

Z H KRUKOWSKI, PHD, FRCSED, lecturer in surgery

M P M STEWART, MB, CHB, senior house officer

H M ALSAYER, MB, FRCSED, lecturer in surgery

N A MATHESON, FRCS, FRCSED, consultant surgeon

Correspondence and requests for references 5-25 to: Mr N A Matheson, Ward 49, Aberdeen Royal Infirmary, Foresterhill, Aberdeen AB9 2ZD.
}

used a consistent combination of surgical techniques to minimise contamination supplemented in its presence by tetracycline lavage of the wound and peritoneal cavity. The volume of lavage fluid used has varied with the degree of operative contamination from 0.5 to $7 \cdot 0$ litres; the measures taken to minimise operative contamination are detailed elsewhere. ${ }^{1}$ This paper presents a prospective audit of wound and peritoneal infection during a consecutive five year period.

\section{Present study}

\section{DEFINITIONS}

Wound infection refers to the discharge of pus or of a serous or sanguineous discharge that grew a pathogenic organism. All patients who at follow up reported a discharge from their wound were considered to have had an infected wound. Wound healing was assessed by several different observers during the five years. It was usual for two people (not necessarily those performing the original operation) to determine the presence or absence of wound infection.

Intraperitoneal abscess was recorded when pus was drained, aspirated, or discharged from the peritoneal cavity or there was radiological, ultrasonic, or necropsy evidence of an intraperitoneal collection.

Operative contamination was classified as follows, based on the American National Research Council criteria ${ }^{2}$ : clean-no infection encountered, no hollow abdominal viscus opened; clean/contaminated -hollow abdominal viscus opened with minimal spillage of contents; contaminated-inflammation without pus formation, viscus opened with gross spillage of contents; dirty-pus encountered or perforated viscus found.

\section{PATIENTS AND METHOD OF DATA COLLECTION}

From January 1977 to December 1981 all patients under the care of NAM and undergoing an abdominal operation were included. 
Information about the patients was recorded on standard forms on completion of the operation, on discharge from or death in hospital, and at follow up four to six weeks after discharge. Some patients failed to attend or were not asked to attend for review because of advanced malignant disease, departure from the region, or after a minor procedure when review would have necessitated an unjustifiable journey. These exceptions were followed up by post either through without subcutaneous sutures and invariable primary skin closure. Intestinal anastomoses were made with a single layer of interrupted braided nylon. ${ }^{4}$ Circular stapling devices became available during the study period but were used in only five of 82 colorectal and coloanal anastomoses and three oesophagojejunal anastomoses. Small bore suction drains were used to drain the peritoneal cavity only after pancreatic or biliary surgery or mobilisation of the rectum.

TABLE I-Incidence of abdominal surgical wounds complicated by infection and intraperitoneal abscesses in 1504 consecutive operations classified by degree of contamination

\begin{tabular}{|c|c|c|c|c|c|c|c|c|c|c|c|}
\hline & \multicolumn{3}{|c|}{ Elective operations } & \multicolumn{3}{|c|}{ Emergency operations } & \multicolumn{3}{|c|}{ All operations } & \multicolumn{2}{|c|}{ Intraperitoneal abscesses } \\
\hline & \multirow{2}{*}{ Total } & \multicolumn{2}{|c|}{ Infected } & \multirow{2}{*}{ Total } & \multicolumn{2}{|c|}{ Infected } & \multirow{2}{*}{ Total } & \multicolumn{2}{|c|}{ Infected } & \multirow{2}{*}{ No } & \multirow{2}{*}{$\%$} \\
\hline & & No & $\%$ & & No & $\%$ & & No & $\%$ & & \\
\hline $\begin{array}{l}\text { Clean } \\
\text { Clean/contaminated } \\
\text { Contaminated } \\
\text { Dirty }\end{array}$ & $\begin{array}{r}293 \\
409 \\
267 \\
16\end{array}$ & $\begin{array}{r}12 \\
7 \\
5 \\
1 \\
\end{array}$ & $\begin{array}{l}4 \cdot 1 \\
1 \cdot 7 \\
1 \cdot 9 \\
6 \cdot 3 \\
\end{array}$ & $\begin{array}{r}77 \\
141 \\
130 \\
171\end{array}$ & $\begin{array}{r}1 \\
1 \\
1 \\
14\end{array}$ & $\begin{array}{l}1 \cdot 3 \\
0 \cdot 7 \\
0 \cdot 8 \\
8 \cdot 2\end{array}$ & $\begin{array}{l}370 \\
550 \\
397 \\
187\end{array}$ & $\begin{array}{r}13 \\
8 \\
6 \\
15\end{array}$ & $\begin{array}{l}3.5 \\
1.5 \\
1.5 \\
8.0\end{array}$ & $\begin{array}{l}0 \\
1 \\
3 \\
8\end{array}$ & $\begin{array}{l}0 \\
0 \cdot 2 \\
0 \cdot 8 \\
4 \cdot 3\end{array}$ \\
\hline Total & 985 & 25 & $2 \cdot 5$ & 519 & 17 & $3 \cdot 3$ & 1504 & 42 & $2 \cdot 8$ & 12 & 0.8 \\
\hline
\end{tabular}

TABLE II-Incidence of wound infections by operative procedure*

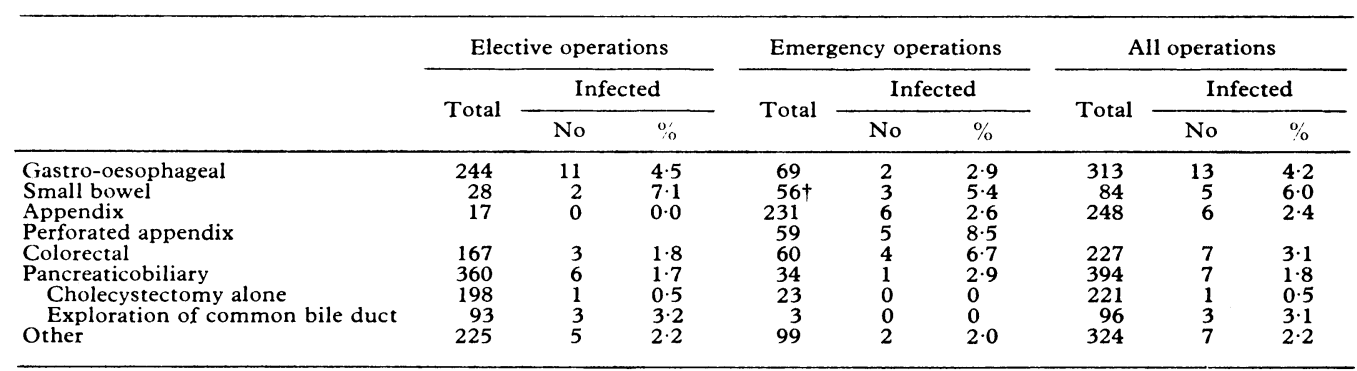

*Column totals exceed 1504 and 42 wound infections; some patients who had two or more operative procedures-for example, highly selective vagotomy and cholecystectomy - feature more than once. †Includes 16 simple sutures of perforated duodenal ulcer.

TABLE III-Incidence of wound infections and rank of operator analysed by degree of operative contamination

\begin{tabular}{|c|c|c|c|c|c|c|c|c|c|c|c|c|}
\hline & Total & No & $\%$ & Total & No & $\%$ & Total & No & $\%$ & Total & No & $\%$ \\
\hline $\begin{array}{l}\text { Clean } \\
\text { Clean/contaminated } \\
\text { Contaminated } \\
\text { Dirty } \\
\end{array}$ & $\begin{array}{l}26 \\
56 \\
46 \\
28 \\
\end{array}$ & $\begin{array}{l}1 \\
0 \\
0 \\
3\end{array}$ & $\begin{array}{l}3 \cdot 8 \\
0 \\
0 \\
10 \cdot 7\end{array}$ & $\begin{array}{r}10 \\
11 \\
8 \\
11\end{array}$ & $\begin{array}{l}0 \\
0 \\
1 \\
1\end{array}$ & $\begin{array}{c}0 \\
0 \\
12 \cdot 5 \\
9 \cdot 1\end{array}$ & $\begin{array}{l}192 \\
280 \\
143 \\
112\end{array}$ & $\begin{array}{l}5 \\
3 \\
0 \\
7\end{array}$ & $\begin{array}{l}2 \cdot 6 \\
1 \cdot 1 \\
0 \\
6 \cdot 3\end{array}$ & $\begin{array}{r}142 \\
203 \\
200 \\
36\end{array}$ & $\begin{array}{l}7 \\
5 \\
5 \\
4\end{array}$ & $\begin{array}{r}4.9 \\
2.5 \\
2.5 \\
11.1\end{array}$ \\
\hline
\end{tabular}

the general practitioner or directly to the patient. Follow up was $97 \cdot 8 \%$ complete.

The information was subsequently transferred to magnetic discs and analysed by a Honeywell $66 / 80$ computer using the statistical package for the social sciences.

\section{SURGICAL MANAGEMENT}

A standard surgical policy was followed throughout. Bowel preparation for elective left sided colonic resection was by whole gut irrigation with 20 litres of solution containing $128 \mathrm{~g} \mathrm{NaCl}, 15 \mathrm{~g} \mathrm{KCl}$, and $60 \mathrm{~g} \mathrm{NaHCO}_{3}{ }^{3}$ and also $20 \mathrm{~g}$ neomycin and $1.6 \mathrm{~g}$ metronidazole. No untoward fluid retention or electrolyte disturbance attributable to whole gut irrigation was observed. Bowel washouts and oral metronidazole the day before operation were used for resection of the right colon. The skin was shaved after induction of anaesthesia and prepared with $0.5 \%$ chlorhexidine in $70 \%$ alcohol. All laparotomies were performed through a vertical midline incision. A midline incision was also used if a diagnosis of perforated appendicitis with generalised peritonitis had been made preoperatively. Wound towels were used routinely supplemented with a plastic ring drape when a hollow viscus was opened, except in uncomplicated cholecystectomy. Incisions were closed with a continuous mass non-absorbable suture

\section{MANAGEMENT OF CONTAMINATION}

In emergency surgery elimination of the source of peritoneal infection including primary resection of colonic lesions was a rule. Left sided colonic anastomosis was avoided as an emergency procedure in unprepared bowel except for four cases late in the series, in which an immediate anastomosis was made after "on table" colonic irrigation. Adequate mechanical preparation was obtained in all the elective cases. All potential or actual peritoneal and parietal contamination was managed with tetracycline lavage $(1 \mathrm{~g} / 1 \mathrm{l} .9 \%$ saline) of the wound and peritoneal cavity together with a single prophylactic preoperative dose of $500 \mathrm{mg}$ tetracycline given intravenously. Therapeutic antibiotics for peritoneal infection extant at the time of operation were given on an individual basis either as intravenous tetracycline or as a combination of antibiotics including metronidazole for three to seven days.

\section{Results}

The audit included all abdominal operations. Between January 1977 and December 1981, 1504 abdominal operations (985 elective and 519 emergency) were performed. Forty patients died in hospital. A total of 42 wound infections occurred $(2 \cdot 8 \%)$, of which 20 were ap- 
parent before discharge from hospital and 22 were detected at follow up. Twelve patients developed postoperative intraperitoneal abscesses $(0.8 \%)$. Table I shows the relation of wound infections and intraperitoneal abscesses to operative contamination. The overall incidence of infection was $2.5 \%$ for elective and $3.3 \%$ for emergency procedures.

Table II lists the rates of wound infection in relation to the type of operative procedure. There was an unexpectedly high incidence of wound infection in the "clean" group of elective gastric operations, attributable to five staphylococcal infections in the 36 highly selective vagotomies performed in 1981 . The overall incidence of wound infection in 248 appendicectomies was $2.4 \%$. When the appendix was gangrenous, perforated, or associated with local pus the incidence was $8.5 \%$. There was one wound infection in 221 cholecystectomies $(0.5 \%)$ and three wound infections in 96 explorations of the common bile duct $(3 \cdot 1 \%)$. Three wound infections occurred after 167 elective colorectal operations $(1.8 \%)$, and the overall incidence in 227 such procedures was $3.1 \%$. The rank of the operator did not materially influence the rate of wound infection (table III).

Seventy six patients received therapeutic antibiotics perioperatively and in 38 this was for peritoneal infection. In 15 cases tetracycline alone was used, and in 23 cases metronidazole alone or in combination with other antibiotics was used. Seven wound infections $(9 \cdot 2 \%)$ developed in these 76 cases.

\section{Discussion}

These results were derived from a busy surgical practice that may be regarded as representative of that likely to be found in any district general hospital. With the possible exception of operations on the stomach and duodenum (which were complicated by a minor staphylococcal epidemic of five cases) the results were considerably better than those commonly published, though comparable rates have been quoted for some groups of operations in North America (table IV)..$^{5-25}$

During the past several years efforts to reduce the incidence of wound infection have concentrated on prophylaxis with antibiotics but wound infection rates may nevertheless remain high, especially in elective colonic surgery (table IV). In "contaminated" and "dirty" emergency operations on the large

TABLE IV-Contemporary experience with wound infection in gastrointestinal surgery

\begin{tabular}{|c|c|c|c|c|c|}
\hline \multirow{2}{*}{$\begin{array}{c}\begin{array}{c}\text { First } \\
\text { author }\end{array}\end{array}$} & \multirow{2}{*}{ Year } & \multirow{2}{*}{$\begin{array}{l}\text { Type of } \\
\text { operation }\end{array}$} & \multirow{2}{*}{$\begin{array}{l}\text { No of } \\
\text { patients }\end{array}$} & \multicolumn{2}{|c|}{$\begin{array}{l}\text { Percentage incidence of } \\
\text { wound infection }\end{array}$} \\
\hline & & & & $\begin{array}{l}\text { Antibiotics } \\
\text { not used }\end{array}$ & $\begin{array}{l}\text { Antibiotics } \\
\text { used }\end{array}$ \\
\hline \multicolumn{6}{|c|}{ Gastric } \\
\hline $\begin{array}{l}\text { Stone } \\
\text { Gatehouse } \\
\text { Hares? }^{\text {? }}\end{array}$ & $\begin{array}{l}1976 \\
1978 \\
1981\end{array}$ & $\begin{array}{l}\text { Elective } \\
\text { Elective } \\
\text { "High risk" }\end{array}$ & $\begin{array}{l}72 \\
73 \\
81\end{array}$ & $\begin{array}{l}22 \\
33 \\
35\end{array}$ & $\begin{array}{l}4 \\
* \\
6\end{array}$ \\
\hline Eastwood $^{8}$ & 1982 & $\{$ "High risk" & 46 & * & 13 \\
\hline Strachan ${ }^{\circ}$ & 1982 & Emergency & $\begin{array}{l}34 \\
98\end{array}$ & 29 & $4 / 27+$ \\
\hline \multicolumn{6}{|c|}{ Biliary } \\
\hline $\begin{array}{l}\text { Stone } \\
\text { Strachan }^{10} \\
\text { Morran }^{11} \\
\text { Gallagher }^{12} \\
\text { MacFarlane }^{13} \\
\text { Keighley }^{14}\end{array}$ & $\begin{array}{l}1976 \\
1977 \\
1978 \\
1982 \\
1982 \\
1982\end{array}$ & $\begin{array}{l}\text { Elective } \\
\text { Elective } \\
\text { Elective } \\
\text { Elective } \\
\text { Elective } \\
\text { Emergency }\end{array}$ & $\begin{array}{r}98 \\
201 \\
95 \\
111 \\
116 \\
17\end{array}$ & $\begin{array}{l}11 \\
17 \\
21 \\
13 \\
13 \\
41\end{array}$ & $\begin{array}{l}2 \\
5 \\
4 \\
8 \\
* \\
*\end{array}$ \\
\hline \multicolumn{6}{|c|}{ Appendix } \\
\hline Bates $^{15}$ & 1980 & $\left\{\begin{array}{l}\text { all } \\
\text { perforated }\end{array}\right.$ & $\begin{array}{r}170 \\
29\end{array}$ & $\begin{array}{l}25 \\
42\end{array}$ & $\begin{array}{l}20 \\
35\end{array}$ \\
\hline Foster ${ }^{16}$ & 1981 & $\left\{\begin{array}{l}\text { all } \\
\text { perforated }\end{array}\right.$ & $\begin{array}{r}375 \\
81\end{array}$ & $\begin{array}{l}29 \\
70\end{array}$ & $\begin{array}{l}17 \\
44\end{array}$ \\
\hline Brennan $^{17}$ & 1982 & Perforated & 71 & $*$ & $74+$ \\
\hline \multicolumn{6}{|c|}{ Colorectal } \\
\hline $\begin{array}{l}\text { Stone } \\
\text { Matheson }^{38} \\
\text { Eykyn }^{10} \\
\text { Aeberhard }^{20} \\
\text { Keighley }^{21} \\
\text { Hughes } \\
\text { Dion } \\
\text { Morris }^{22} \\
\text { Beggs }^{25} \\
\text { Strachan }\end{array}$ & $\begin{array}{l}1976 \\
1978 \\
1979 \\
1979 \\
1979 \\
1979 \\
1980 \\
1982 \\
1982 \\
1982\end{array}$ & $\begin{array}{l}\text { Elective } \\
\text { Elective } \\
\text { Elective } \\
\text { Elective } \\
\text { Elective } \\
\text { Elective } \\
\text { Elective } \\
\text { Elective } \\
\text { Elective } \\
\text { Emergency }\end{array}$ & $\begin{array}{r}149 \\
120 \\
83 \\
52 \\
93 \\
1590 \\
78 \\
96 \\
97 \\
87\end{array}$ & $\begin{array}{r}16 \\
42 \\
64 \\
* \\
* \\
38 \\
* \\
* \\
*\end{array}$ & $\begin{array}{l}6 \\
18 \\
30 \dagger \\
11 / 16 \dagger \\
7 / 37 \dagger \\
15 \\
3 / 8 \dagger \\
24 / 28 \dagger \\
10 / 13 \dagger \\
45 / 54 \dagger\end{array}$ \\
\hline
\end{tabular}

*Not included.

Results from comparative trial of two antibiotic regimens

Pathogenic bacteria grown in unsutured wounds. bowel and appendix, where antibiotic usage may be more correctly termed therapeutic, wound infection rates of up to $40 \%$ persist. ${ }^{9} 1516$

Because our results have been achieved by a package of techniques we cannot say which factor or factors are responsible. The differences between our results and those reported with conventional antibiotic use become more pronounced with increasing degrees of contamination, supporting our belief that routine use of tetracycline lavage is an important component of our regimen. The incidence of $8.5 \%$ in gangrenous and perforated appendicitis was identical with that reported by us in children with generalised peritonitis treated in the same way. ${ }^{26}$ That in only four $(7 \cdot 6 \%)$ of 53 "contaminated" and "dirty" emergency colorectal procedures did the wound become infected is strong supportive evidence that tetracycline lavage is particularly effective in emergency cases with peritoneal and parietal contamination. The incidence of residual or recrudescent intraperitoneal infection of $11(1.9 \%)$ in 584 "contaminated" and "dirty" cases compared with that of $10-20 \%$ commonly reported is further evidence to support the use of tetracycline lavage. ${ }^{27-29}$

Tetracycline lavage was introduced in 1964 when the choice of a broad spectrum antibiotic for topical use was limited, and its association with the results obtained has supported an argument for no change. The greatly increased activity of tetracycline against both anaerobic and aerobic bacteria at the high concentration used in lavage is well documented ${ }^{30}$ and has recently been confirmed in isolates from generalised peritonitis in patients in Aberdeen. ${ }^{31}$

Though clinical trials are methods of assessing new procedures, accurate information about current results produced by a team provide the logical basis on which to modify or not the practice of that team. If the results are a consistent improvement on those obtained by clinical trials then the latter are no longer a basis for decision making. Finally, it is almost certain, although difficult to document, that the accurate and obsessional collation of data is a continued spur to a high standard of performance. ${ }^{32}$

We are grateful to Aberdeen University Computer Centre for providing computing facilities.

\section{References}

${ }^{1}$ Krukowski $\mathrm{ZH}$, Matheson NA. The management of peritoneal and parietal contamination in abdominal surgery. Br F Surg 1983;70:440-1.

2 National Academy of Sciences-National Research Council. Division of Medical Sciences Ad Hoc Committee of the Committee on Trauma. Post-operative wound infections; the influence of ultraviolet irradiation of the operating room and various other factors. Ann Surg 1964; suppl 12.

${ }^{3}$ Hewitt J, Reeve J, Rigby J, Cox AG. Whole gut irrigation in preparation for large bowel surgery. Lancet 1973;ii:337-40.

- Matheson NA, Irving AD. Single layer anastomosis in the gastrointestinal tract. Surg Gynecol Obstet 1975;143:619-24.

5- 25 References available on request from NAM.

26 Stewart DJ, Matheson NA. Peritoneal lavage in appendicular peritonitis. $B r \mathcal{F}$ Surg 1978;65:54-6.

${ }^{27}$ Rambo WM. Irrigation of the peritoneal cavity with cephalothin. $A m \mathcal{F}$ Surg 1972;123:192-5.

${ }^{28}$ Minervini S, Youngs D, Alexander-Williams J, Burdon DW, Keighley MRB. Prophylactic saline peritoneal lavage in elective colorectal operations. Dis Colon Rectum 1980;23:392-4.

29 Sindelar WF, Mason GR. Intraperitoneal irrigation with povidone-iodine solution for the prevention of intra-abdominal abscesses in bacterially contaminated abdomens. Surg Gynecol Obstet 1979;148:409-11.

${ }^{30}$ Steigbigel NH, Reed CW, Finland M. Susceptibility of common pathogenic bacteria to seven tetracycline antibiotics in vitro. $\mathrm{Am} \mathcal{F ~ M e d ~ S c i}$ $1968 ; 255$ : 179-95.

${ }^{31}$ Krukowski ZH, Al-sayer HM, Reid TMS, Matheson NA. The effect of peritoneal lavage on the bacterial load and bacterial growth kinetics in generalised peritonitis in man. Br $\mathcal{f}$ Surg (in press).

32 Cruse PJE, Foord R. The epidemiology of wound infection. A ten year prospective study of 62,939 wounds. Surg Clin North Am 1980;60: 27-40.

(Accepted 27 October 1983) 